\title{
THE STONOR LETTERS AND PAPERS
}




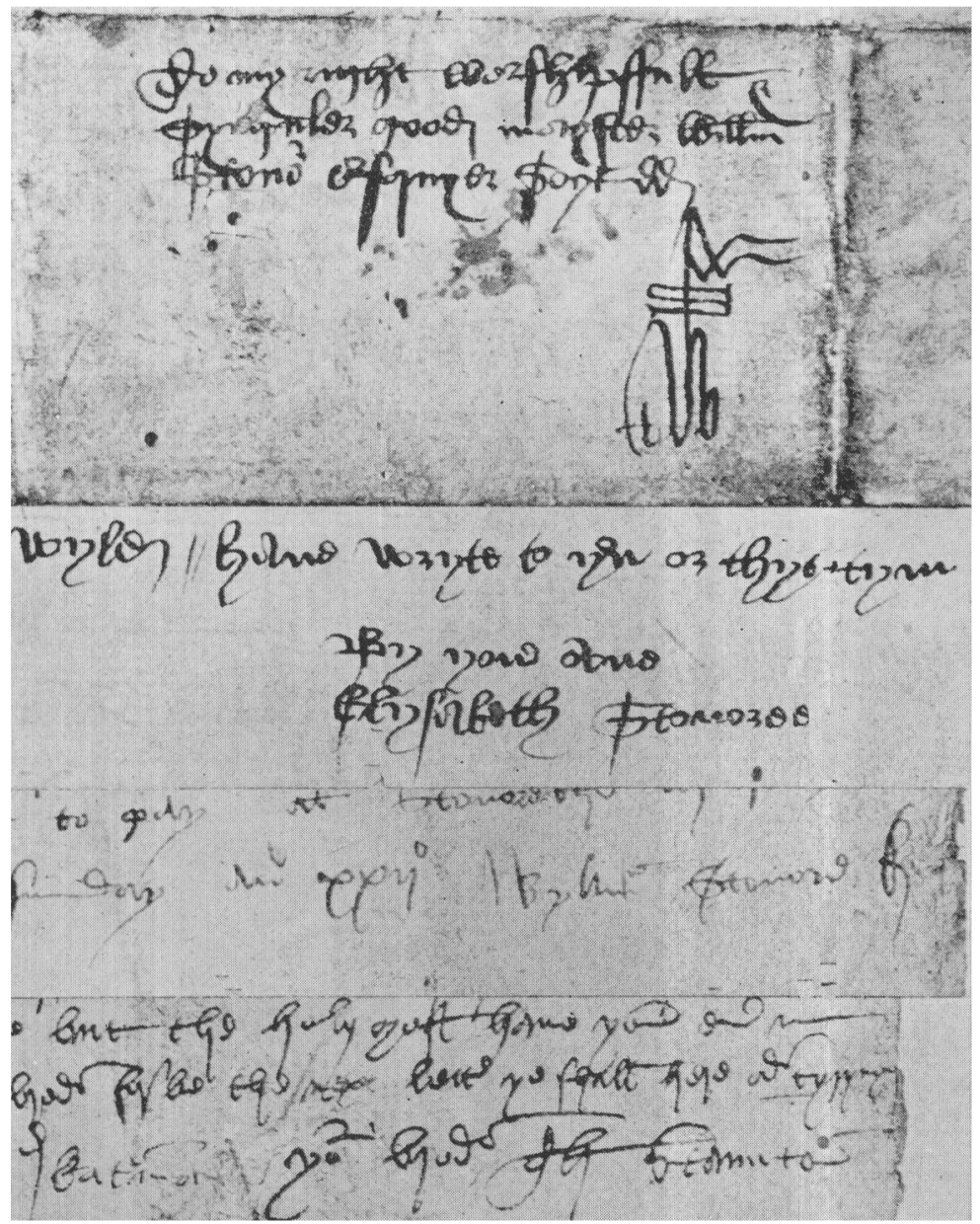

Signaturies from the Stonor Papers

I. Merchant's Mark of Sir William Stonor. (From No. 162)

2. Elizabeth Stonor. (From No, rg)

3. Sir William Stonor. (From No. $3^{15}$ )

4. Thomas Staunton or Stonor. (From No. I53) 


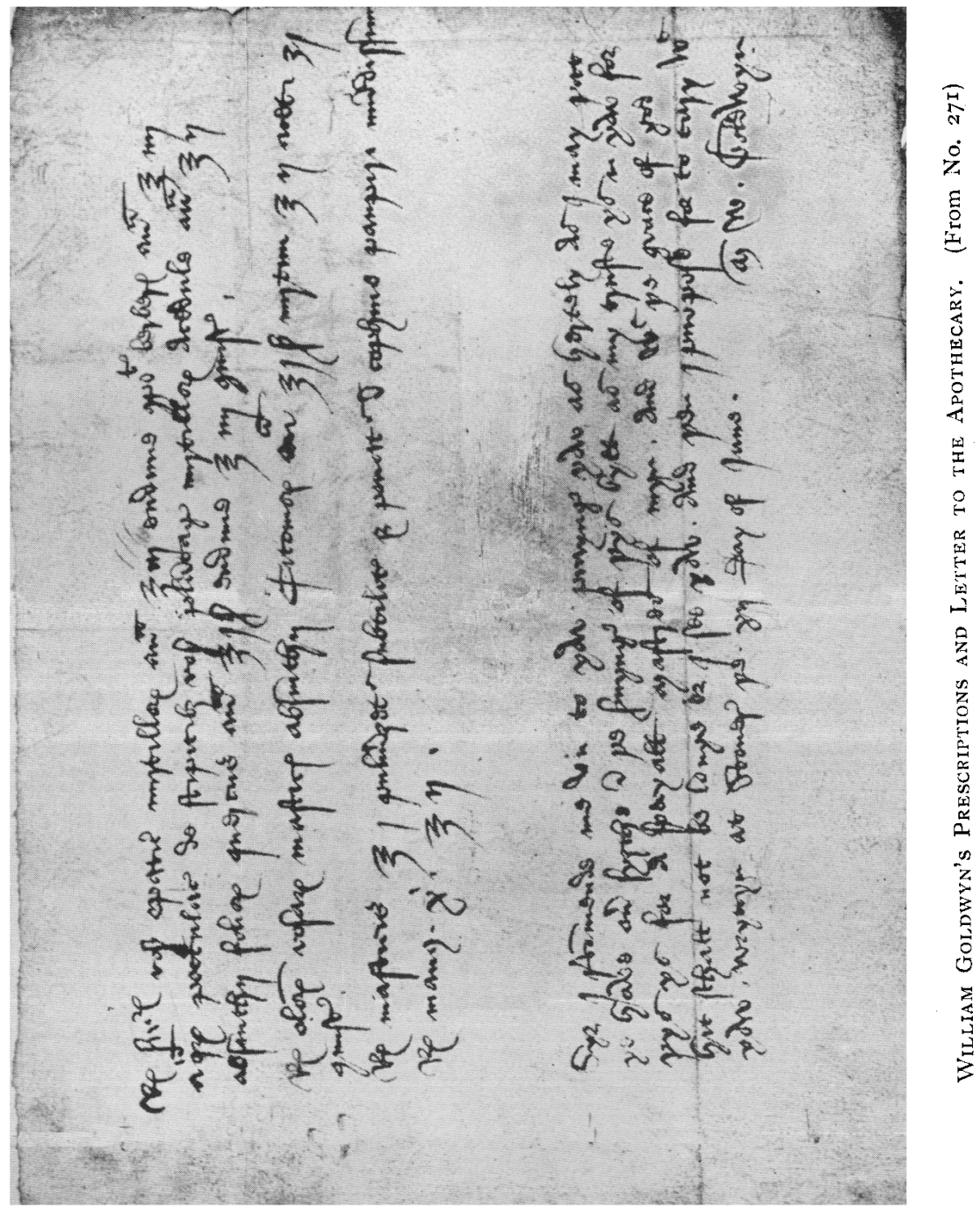




\title{
THE STONOR LETTERS AND PAPERS I $290-1483$
}
EDITED, FOR THE ROYAL HISTORICAL SOCIETY, FROM THE ORIGINAL DOCUMENTS IN THE PUBLIC RECORD OFFICE BY

\section{CHARLES LETHBRIDGE KINGSFORD M.A., F.S.A.}

VOL. II.

CAMDEN THIRD SERIES

VOL. $X X X$.

\author{
LONDON \\ OFFICES OF THE SOCIETY \\ 22 RUSSELL SQUARE, W.C. I \\ I9I9
}




\title{
CONTENTS OF VOL. II.
}

ThE Srovor Pasi:

The Stonor Leterters and Papers (continued) • • • • • • . $\quad x$

\begin{abstract}
APPENDIX.
I. Miscellaneous Stonor MSS.

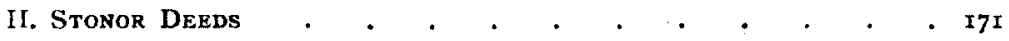

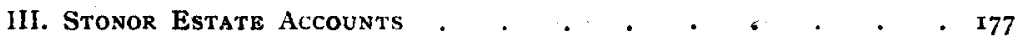

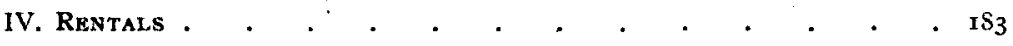

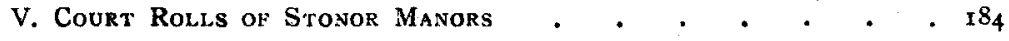

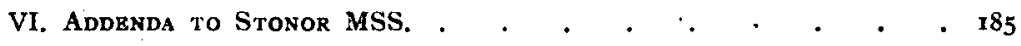

InDEX to Stonor LetTers IN ANCIENT CORRESPONDENCE + . . 188

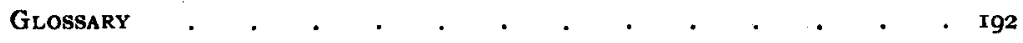

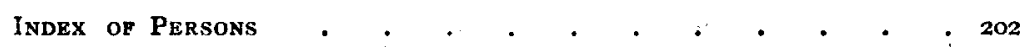

INDEX of Places . . . . . . . . . . . . . . . . . 217

Facsimiles of Stonor Signatures . . . . . . . . Frontispiece

Facsimile of Goldwyn's Prescriptions . . . . To face page to8
\end{abstract}

